\title{
PEWARNAAN BATIK TULIS MENGGUNAKAN PEWARNA ALAMI DAN BAHAN FIKSASI KITOSAN PADA KELOMPOK BATIK TULIS ASIH MATAHARI KOTA BLITAR
}

\author{
Oleh: \\ Dina Kartika Maharani ${ }^{1}$, Siti Tjahjani ${ }^{1}$, Nita Kusumawati ${ }^{1}$ \\ ${ }^{1}$ Universitas Negeri Surabaya \\ 1dinakartika@unesa.ac.id
}

\begin{abstract}
Abstrak
Pengembangan inovasi proses produksi batik tulis meliptui proses pewarnaan dan desain motif merupakan faktor penting untuk meningkatkan penjualan dan kapasitas produksi. Kota Blitar memiliki produksi batik khas yang dikenal dengan motif ikan koi. Batik Blitar belum populer di kalangan masyarakat, sehingga pelatihan dan pendampingan terkait proses pewarnaan dengan pewarna alam perlu dilakukan. Tujuan pelatihan adalah untuk meningkatkan ketrampilan mitra dalam proses pewarnaan menggunakan pewarna alami dan agen fiksasi. Kegiatan pelatihan dilakukan terhadap kelompok mitra batik Asih Matahari kota Blitar. Pelatihan yang dilakukan meliputi pelatihan pembuatan pewarna alam dan penggunaan agen fiksasi ramah lingkungan Kitosan pada proses pewarnaan batik tulis. Hasil pelatihan didapatkan bahwa mitra berhasil membuat pewarna alam dan melakukan proses fiksasi pewarna alam dengan Kitosan. Respon mitra terhadap pelatihan menunjukkan antusiasme dan ketertarikan yang tinggi.
\end{abstract}

Kata Kunci: batik tulis, pewarna alam, kitosan, fiksasi

\begin{abstract}
Development on batik production processes inovation including dyeing process and pattern design become one of important factors that increase selling and production. Blitar city has unique batik product namely koi fish batik. The product is less popular among others batik from different city, so training on dyeing process with natural dye are essential to do. The objective of the training were to improve skill of dyeing process. The training for batik tulis group partner which Asih Matahari group included introduction of natural dye for batik dyeing and introduction of eco friendly fixation agent for dyeing process and use of padder tools to improve efficiency of dye coating process. The result of the training showed that batik group can use natural dye and do the dyeing with fixation agent Chitosan. Response of the training member showed high enthusiasm and interested toward training.
\end{abstract}

Keywords: batik, natural dye, fixation, chitosan

\section{PENDAHULUAN}

Kota Blitar merupakan salah satu kota di Jawa Timur yang juga memiliki sentra industri batik tulis maupun cap yang tersebar di berbagai kecamatan seperti Sanan Wetan, Sukorejo, dan beberapa daerah di kabupaten Blitar. Batik Blitar, meskipun terbilang masih kurang populer di masyarakat umum dan tertinggal dengan daerah lain yang lebih dikenal akan motif batiknya terus berupaya mengembangkan kreasi corak, motif dan desain batik khasnya. Pemkot Blitar semakin serius melakukan pemberdayaan pengrajin batik di wilayahnya (Faishol, A. 2015).

Sejarah batik Blitar dimulai sejak tahun 1902 dengan motif tumbuhan dan binatang sebagai simbol utama dalam sebuah cerita atau yang disebut tutur. Seiring berkembangnya waktu, motif batik Blitar mengalami perubahan corak dan variasi motif seperti motif wentar, motif jumputan dan motif lain. Salah satu pengrajin batik di kota Blitar adalah Ibu Asih Yustina yang merintis usaha batik khas kota Blitar yaitu batik Asih Matahari yang beralamatkan di Jalan Sukin nomor 77 kota Blitar. Berbagai motif batik telah diproduksi oleh Ibu Asih Yustina seperti motif ikan koi, blimbing, otok-otok dan teratai dengan berbagai ukuran. Batik Asih Matahari selama ini masih didominasi oleh batik dengan pewarna sintetis. Penggunaan pewarna alami masih sangat minim diketahui oleh pengrajin batik di daerah Blitar. Keterbatasan pengetahuan pengrajin batik tentang teknik proses pewarnaan batik menggunakan pewarna alami maupun cara pembuatannya menjadi persoalan yang dihadapi oleh para pengrajin batik kota Blitar mengembangkan batik dengan bahan pewarna alami yang bernilai jual tinggi. Salah 
satu kendala pewarnaan kain batik (mori) menggunakan zat warna alam adalah variasi warnanya sangat terbatas dan ketersediaan bahannya yang tidak siap pakai sehingga diperlukan proses-proses khusus untuk dapat dijadikan larutan pewarna mori. Oleh karena itu pewarna alami dianggap kurang praktis penggunaannya. Selain itu karena terbuat dari bahan-bahan alami, pewarna alami relatif tidak seawet pewarna kimia. Hal ini menyebabkan warna batik cenderung cepat memudar jika dicuci dengan detergen biasa. Namun dibalik kekurangannya zat warna alam memiliki potensi pasar yang tinggi sebagai komoditas unggulan produk Indonesia. Untuk mengatasi hal tersebut maka diperlukan kegiatan pelatihan pemanfaatan bahan-bahan alami sebagai pewarna alami batik tulis di kota Blitar serta proses pewarnaan batik yaitu dengan cara pemberian agen fiksasi untuk zat warna alami.

Beberapa cara fiksasi sebagai penguat warna atau ada yang menyebut pengunci warna, supaya warna tidak luntur dan menempel kuat pada kain / media batik dicelup kedalam larutan alkali atau asam seperti asam klorida atau asam sulfat. Namun kedua jenis asam tersebut sangat berbahaya bagi lingkungan dan bersifat toksik. Apabila bahan tersebut kontak dengan kulit akan menjadi iritasi ringan dan mudah melepuh atau menyebabkan rasa gatal pada kulit (Trismawati, dkk., 2010). Apabila terhirup menyebabkan terpapar diparu-paru dan akan menyebabkan nafas terasa sesak atau sakit di ulu hati dan apabila kontak dengan mata akan menyebabkan iritasi ringan. Sisa larutan fiksasi dengan asam klorida $(\mathrm{HCl})$ juga berpotensi menjadi limbah cair yang berbahaya bagi lingkungan, sehingga air sisa fiksasi perlu diolah ke dalam IPAL (Instalasi Pengolahan Air Limbah). Untuk mengatasi hal tersebut maka perlu alternatif lain sebagai agen fiksasi yang lebih ramah lingkungan. Biopolimer kitosan merupakan salah satu agen fiksasi yang bersifat ramah lingkungan serta memiliki performa yang baik untuk meningkatkan ketahanan luntur zat warna pada batik (Fouda, 2005). Material tersebut dapat digunakan sebagai pengganti agen fiksasi yang bersifat toksik dan berbahaya bagi lingkungan seperti $\mathrm{HCl}$.

Berdasarkan hasil pengamatan terhadap pengrajin batik kota Blitar yaitu pengrajin batik Asih Matahari maka tim PKM jurusan Kimia FMIPA Universitas Negeri Surabaya melakukan upaya pengembangan proses pewarnaan batik kota Blitar menggunakan pewarna alam dengan pemberian bahan fiksasi ramah lingkungan untuk meningkatkan daya jualnya.

Oleh karena itu dalam usulan kegiatan PKM ini akan diusulkan kegiatan pelatihan dan pendampingan kepada mitra pengrajin batik Asih Matahari kota Blitar tentang konsep pembuatan pewarna alam serta proses pewarnaan batik menggunakan bahan fiksasi ramah lingkungan.

\section{METODE}

Metode yang digunakan dalam kegiatan PKM ini adalah pelatihan dan konsultasi terkait proses pewarnaan batik dengan pewarna alam.

\section{Sasaran kegiatan}

Sasaran kegiatan pelatihan adalah ibu-ibu dan muda-mudi pengrajin batik yang tergabung dalam kelompok batik tulis Asih Matahari kota Blitar

\section{Tempat Kegiatan}

Tempat kegiatan adalah di lokasi mitra kelompok batik tulis Asih Matahari jalan Sukun nomor 77 Blitar

\section{Prosedur Pelaksanaan}

Kegiatan pelatihan ini terdiri dari beberapa tahap yaitu ;

a. Tim pengusul memberikan penyuluhan dan pendampingan tentang pemanfaatan bahan-bahan alami sebagai pewarna alami batik tulis khas kota Blitar dalam rangka menghasilkan batik tulis yang elegan dan bernilai jual tinggi.

b. Tim pengusul memberikan pelatihan dan pendampingan tentang penggunaan bahan fiksasi kitosan pada proses pewarnaan batik

c. Tim pengusul melakukan pendampingan tentang proses pewarnaan batik pada pengrajin batik Asih Matahari

d. Tim pengusul melakukan evaluasi terhadap hasil penerapan proses pewarnaan batik

\section{HASIL DAN PEMBAHASAN}

Kegiatan pelatian pelatihan proses pewarnaan batik menggunakan pewarna alami dan bahan fiksasi ramah lingkungan dilaksanakan di tempat mitra kelompok batik Asih Matahari yang beralamatkan di jalan Sukun nomer 77 kota Blitar. Kegiatan pelatihan diikuti oleh ketua mitra Batik Asih Matahari serta beberapa anggota kelompok 
mitra dengan tahapan kegiatan diawali dengan penyampaian penjelasan materi tentang pewarna alami dan bahan fiksasi secara umum kemudian dilanjutkan dengan penjelasan materi tentang penggunaan bahan fiksasi dari kitosan untuk pewarnaan batik serta prospek usaha batik tulis menggunakan pewarna alami dan bahan tambahan fiksasi kitosan yang dapat menghasilkan fungsi tambahan pada kain batik yaitu sifat tahan luntur dan antibakteri.

Penyampaian materi dilakukan dengan metode ceramah dan diikuti dengan diskusi dan tanya jawab. Selama penyampaian materi tentang pewarna alami dan bahan fiksasi dari kitosan, mitra antusias untuk menyimak penjelasan dari narasumber karena materi tersebut merupakan materi baru bagi mitra kelompok batik Asih Matahari yang belum pernah mengetahui manfaat kitosan untuk proses pewarnaan batik. Berdasarkan hasil angket respon mitra sebanyak $88 \%$ dari total peserta menyukai materi karena merupakan pengetahuan baru. Materi yang disampaikan pada kegiatan ini meliputi jenis-jenis pewarna alam batik, cara pembuatan pewarna alam batik, pemanfaatan kitosan sebagai bahan fiksasi batik yang ramah lingkungan dan meningkatkan nilai jual batik serta prospek pemasaran usaha batik dengan pewarna alam.

Kegiatan selanjutnya yaitu pelaksanaan pelatihan tentang proses pewarnaan batik menggunakan pewarna alami dan bahan fiksasi ramah lingkungan. Mitra kelompok batik Asih Matahari berpartisipasi dalam kegiatan pelatihan pewarnaan batik yaitu menyediakan sarana untuk proses penyiapan larutan pewarna alam serta melakukan uji coba pewarnaan kain menggunakan pewarna alami maupun penambahan bahan fiksasi ramah lingkungan dari kitosan. Pelatihan pewarnaan batik dengan pewarna alami dan bahan fiksasi ramah lingkungan ini diikuti oleh seluruh peserta pelatihan dengan menggunakan bahan dasar yang diberikan oleh narasumber yaitu berupa pewarna alam jalawe, mahoni, jambal serta kain untuk pencelupan. Kegiatan pelatihan diawali dengan penjelasan tentang tata cara penyiapan atau prosedur penyiapan larutan pewarna alam kemudian dilanjutkan dengan demonstrasi penyiapan larutan pewarna alam serta diikuti dengan praktek pembuatan pewarna alam jambal oleh beberapa orang peserta. Masing-masing peserta diberikan modul atau handout tentang prosedur pembuatan pewarna alam.
Proses pembuatan pewarna alam diawali dengan merebus air sebanyak 1 liter selanjutnya memasukkan pewarna alam ke dalam air dan direbus sampai volumenya setengah dari volume awal. Untuk kegiatan pembuatan bahan fiksasi ramah lingkungan dilakukan dengan melarutkan serbuk kitosan ke dalam larutan asam asetat.

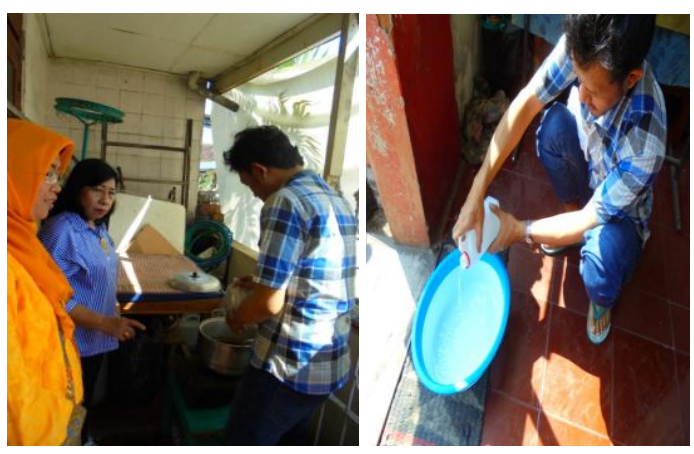

Gambar 1. Proses pembuatan larutan pewarna alam dan bahan fiksasi kitosan

Setelah dilakukan pembuatan pewarna alam dan penyiapan larutan fiksasi kitosan, tahap kegiatan pelatihan pencelupan kain ke dalam pewarna alam dan bahan fiksasi ramah lingkungan kitosan. Proses pencelupan kain pada pewarna alam dilakukan untuk pewarna alam jambal yang telah disiapkan pada tahap sebelumnya. Tahap pencelupan dibagi menjadi 3 jenis tahapan pencelupan yaitu yang pertama pencelupan kain ke dalam larutan pewarna alam dilanjutkan dengan bahan fiksasi kitosan, yang kedua yaitu pencelupan kain ke dalam bahan fiksasi kitosan dilanjutkan dengan larutan pewarna alam dan yang ketiga adalah pencelupan kain ke dalam campuran larutan pewarna alam dan bahan fiksasi kitosan. Kain hasil pencelupan selanjutnya dijemur di sinar matahari. Berdasarkan hasil uji coba proses pewarnaan kain dengan pewarnaan alam dan bahan fiksasi ramah lingkungan kitosan, didapatkan bahwa kain dengan proses pencelupan tahap pertama menghasilkan intensitas warna alami yang paling tajam.

Secara umum peserta pelatihan antusias mengikuti kegiatan pelatihan pewarnaan batik dengan pewarna alam dan bahan fiksasi kitosan. Hal ini dibuktikan dengan hasil angket respon peserta yang menyatakan bahwa peserta tertarik dengan pelaksanaan kegiatan pelatihan pembuatan pewarna alam batik dan pewarnaan dengan bahan fiksasi ramah lingkungan. 

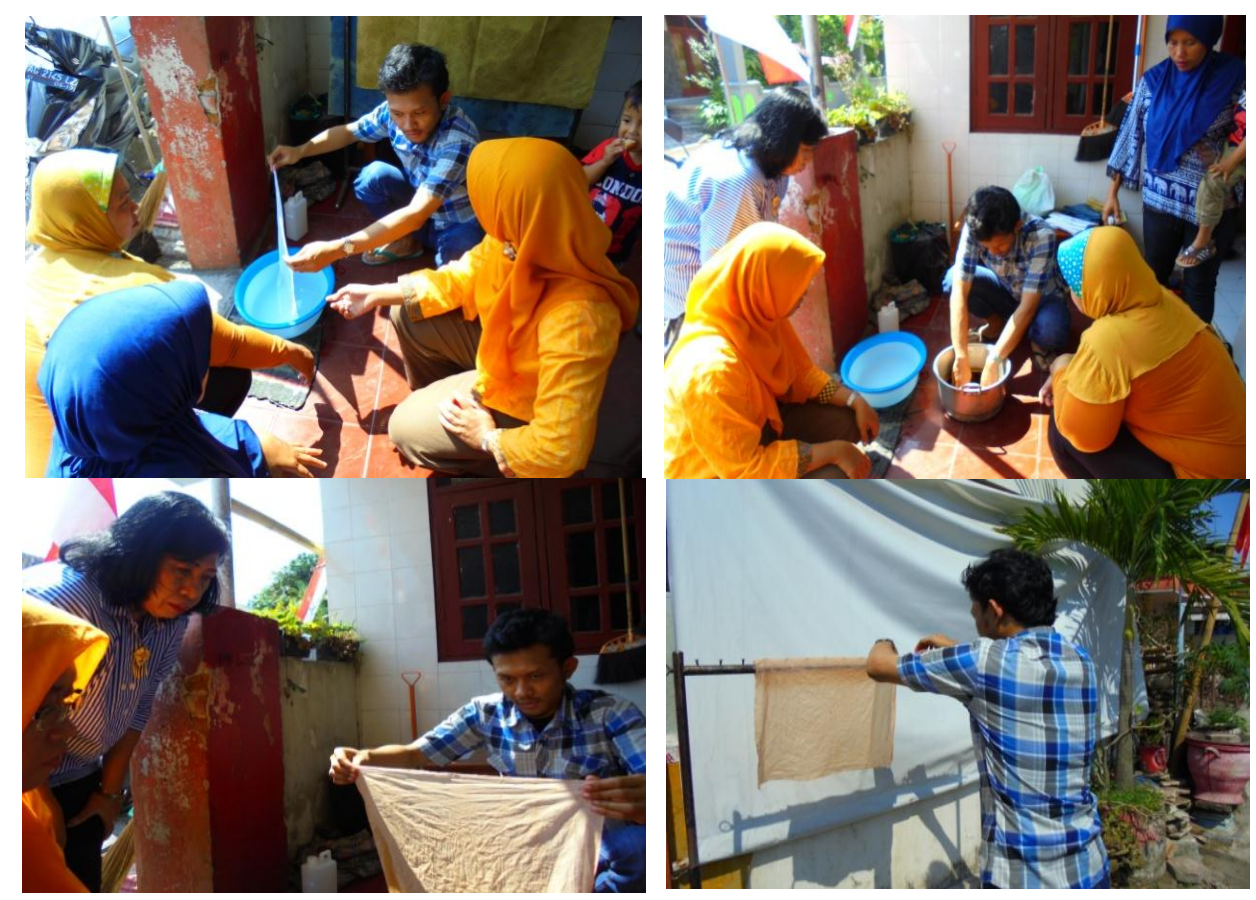

Gambar 1. Proses pembuatan larutan pewarna alam dan bahan fiksasi kitosan

\section{SIMPULAN DAN SARAN}

Berdasarkan hasil kegiatan pengabdian di mitra kelompok batik Asih Matahari kota Blitar dapat disimpulkan bahwa pelatihan pewarnaan batik menggunakan pewarna alam dan bahan fiksasi ramah lingkungan berlangsung dengan lancar dan tertib dan diikuti oleh 8 peserta melalui metode ceramah, diskusi dan praktek. Peserta kegiatan memberi respon yang sangat baik terhadap kegiatan pelatihan. Hal ini ditandai dengan antusiasnya peserta pada sesi tanya jawab serta jawaban angket yang diberikan yaitu sebanyak $100 \%$ peserta tertarik dengan materi pelatihan, sebanyak $88 \%$ peserta menyatakan bahwa materi pelatihan merupakan pengetahuan baru.

\section{Saran}

Saran dari kegiatan pelatihan ini adalah mitra diharapkan dapat mengoptimalkan pewarna alam sebagai pewarna batik tulis dengan menambahkan agen fiksasi dalam jumlah yang sesuai sehingga dapat meningkatkan daya jual batik tulis pewarna alam

\section{DAFTAR PUSTAKA}

Faishol, A. 2015. Batik Blitar. Situs : http://www.blitarkab.go.id. Diakses tanggal 15 April 2017.

Fouda, M.M.G., 2005, Use of Polysacharides in Medical Textile Applications, Dissertation, Universitat Duissburgessen, Germany.

Herlina, Sri, artikel penelitian tentang fiksasi bahan alami dari buah markisa dan jeruk nipis dalam proses pewarnaan batik dengan zat warna indigosol, PPPTK Seni dan Budaya Yogyakarta

Trismawati K., Setyabakti, V., Rosetyo, C.W., 2010. Pencelupan pada kain sutera menggunakan zat warna urang aring (eclipta alba) dengan fiksator tawas, tunjung dan kapur tohor, Laporan PKMP, Universitas Negeri Yogyakarta 